УДК 174:378.091.113

Сушик I.В., к. іст. н., доцент Sushyk I. Candidate of Historical Sciences, Associate Professor https://orcid.org/ 0000-0002-4620-5453

Сушик О.Г., к. пед. н., доцент Sushyk O. Candidate of Pedagogical Sciences, Associate Professor https://orcid.org/0000-0003-2223-4070

\title{
ФОРМУВАННЯ КОРПОРАТИВНОЇ КУЛЬТУРИ ЗАКЛАДУ ПРОФЕСІЙНО- ТЕХНІЧНОЇ ОСВІТИ ЯК СКЛАДОВА УПРАВЛІНСЬКОЇ КОМПЕТЕНТНОСТІ КЕРІВНИКА
}

\author{
Луизький національний технічний університет
}

\begin{abstract}
Освітня інституція України переживає нелегкі часи. Особливо це стосується закладів професійнотехнічної освіти, які в переважній своїй більшості лише стають на шлях оновлення. Реформування професійно-технічної освіти відбувається повільно. Ця освітянська ланка ще не посіла належного місця у загальному процесі перебудови суспільного виробництва і відтворення трудових ресурсів країни, хоча й має такий потенціал. Трансформацію професійно-технічної освіти сучасні фахівці розглядають комплексно, як філософську, соціально-економічну та педагогічну проблему. Традиційна модель професійно-технічної освіти, заснована на радянській спадщині жорсткої централізації та управління, вичерпала себе і потребує оновлення та модернізації.

Затребуваність на випускників професійних (професійно-технічних) училищ в Україні щороку зростає. Однак держава не в змозі справитися з проблемою налагодження роботи цих закладів через економічні, фінансові та ряд інших причин, що накопичилися за роки. Зміни сучасного суспільства, в тому числі в освітній сфері, вимагають керівників нового рівня.

Актуальності набуває управлінська компетентність керівника щодо формування корпоративної культури організації. Доведено, що робота злагодженої команди $є$ більш ефективною, ніж індивідуалізована праця, навіть високопрофесійна. Великі компанії, які стали світовими лідерами, вже давно відчули взаємозв’язок продуктивності праці від духовного й психологічної комфорту, ступеню єдності та спільності працівників. Корпоративна культура є стратегічним маркетинговим ресурсом, ефективним інструментом управління в руках керівника. Практика роботи багатьох організацій засвідчує, що ділова єдність залежить безпосередньо від духу та атмосфери, яка створюється в організації.

Новий компетентнісний підхід, за яким працюють університети Свропи з кінця ХХ ст. та активно впроваджується в Україні, вимагає підготовки особистості керівника, котрий в майбутньому володітиме не лише сумою знань, вмінь і навичок, а зможе діяти, приймати рішення в нестандартних ситуаціях. Важлива психологічна готовність керівника, уміння підготувати колектив до роботи в умовах соціальних та освітніх трансформацій.
\end{abstract}

Ключові слова: корпоративна культура, управлінська компетентність, управлінська культура, менеджер освіти.

\section{FORMATION OF THE CORPORATE CULTURE INSIDE EDUCATIONAL INSTITUTION AS A PART OF DEVELOPMENT MANAGEMENT SKILLS AND COMPETENCE OF MANAGERS}

\author{
Lutsk National Technical University
}

Institution of education in Ukraine is going through difficult times. This is especially true for technical education institutions which for the most part are only on the path to renewal. Reformation of technical education institutions is rather slow. This educational link has not yet taken its rightful place in general process of restructuring of national production and reproduction of country's labour force, although such potential exists. Modern experts view it as a complex issue with philosophical, socio-economic and pedagogical problems. The traditional model of technical education was based on the Soviet legacy of rigid centralization and management, nowadays exhausted itself and needs to be renewed and modified.

Demand for technical education graduates is growing every year. However, the state is unable to cope with problems of establishing these institutions due to economic, financial and number of other reasons that have accumulated over the years. Changes in modern society, including field of education, require leaders of a new 
level. Managers competence and skill level is important in establishing corporate culture. It is proven that work of a well-coordinated team is much more productive than input of individual employee.

Corporations that have become world leaders have long felt the relationship between productivity, psychological and spiritual comfort, unity of employees. Corporate culture is a strategic marketing resource, an affective tool in hands of a good leader. The practice of many companies shows that business unity depends directly on the spirit and atmosphere created in the company.

The new approach taken by European universities has been working since the end of twentieth century and being actively implemented in Ukraine. It requires coaching personality of the leader who in the future not only will accumulate knowledge and skills, but will be able to act and make decisions in extraordinary sutiations. Psychological refined of the leader, the ability to prepare the team to work in conditions of social and educational transformations is extremely important.

Key words: Corporate culture, Management competence, Management culture, Manager of education.

Постановка проблеми у загальному вигляді i iї зв'язок 3 важливими науковими та практичними завданнями. Соціально-економічні зміни сучасного суспільства, в тому числі в освітній сфері, вимагають керівників нового рівня. Суспільству потрібні ініціативні, творчі, самостійні, успішні, креативні лідери, які вміють реалізувати себе на ринку праці і нести відповідальність за результати своєї діяльності. Висока культура управління має стати основою нового економічного менталітету в усіх сферах життя і насамперед в освітній галузі, яка закладає основи моралі й етики взаємин, культури підприємницької праці, задає тон для подальшої трудової діяльності своїх випускників. Лише компетентні фахівців 3 високою управлінською культурою здатні сформувати міцний колектив однодумців 3 високою корпоративною культурою.

Аналіз останніх досліджень, у яких започатковано вирішення проблеми. Дослідження питань формування та розвитку корпоративної культури стають все актуальнішими в науковій літературі. Феномен корпоративної культури та його вплив на життєдіяльність організації вивчають педагоги, психологи, менеджери. Важливість формування корпоративної культури відображена у працях К. Камерона, Р. Куїна, Ч. Хенді, Е. Шейна та ін. Головна роль у іiі формуванні відведена саме керівникові.

Питання управлінської компетентності керівників закладів освіти знайшли своє відображення у працях вітчизняних учених, зокрема В. Бондара, Р. Вдовиченко, Л. Даниленко, В. Маслова, В. Мельник та ін. Більшість науковців схильні вважати, що саме керівник формує здорову атмосферу в організації, а це вимагає управлінської компетенції. Сучасний освітній менеджмент говорить про можливості удосконалення управління сучасних закладів освіти через модернізацію функцій керівника. Поряд 3 виконанням традиційних функцій керівник має володіти прогностичною, консультативною, представницькою, менеджерською та політикодипломатичною функціями. Діяльність керівника виходить далеко за межі педагогічних знань, i відповідно є поліфункціональною, полідіяльнісною, вимагає знань 3 різних царин життя і науки.

Новий компетентнісний підхід, за яким працюють університети Європи з кінця XX ст. та активно впроваджується в Україні, вимагає підготовки особистості керівника, котрий в майбутньому володітиме не лише сумою знань, вмінь і навичок, а зможе діяти, приймати рішення в нестандартних ситуаціях, матиме здатність розвиватися, враховуючи природні нахили людини, задатки. Йдеться про такі компетенції як готовність, здатність і володіння.

Виходячи із сказаного актуальними серед науковців $є$ дослідження психологічної готовності керівників до забезпечення конкурентоздатності освітніх організацій в умовах соціальних та освітніх трансформацій. 3 цією метою вченими розробляються технології розвитку психологічної готовності керівників освітніх організацій. Дана проблема викладена у працях С. Сисоєвої, Л. Карамушки [1], О. Бондарчук [2]. 
Затребуваними на сьогодні $\epsilon$ аналіз теорій управлінських якостей, до яких звертаються дослідники Р. Кричевський, Л. Кудряшова. Порівняно новою для осмислення і не менш затребуваною є емоційна компетентність керівника, якій більше уваги приділено в зарубіжній історіографії (Д. Гоулман)[3], проте в останні роки вона стає предметом активних наукових розвідок у вітчизняних вчених (I. Ясточкіна [4], В. Зарицька [5], Ю. Бреус [6] та ін.)

Цілі статті. Розкрити важливість управлінської компетентності керівника у формуванні корпоративної культури професійно-технічного закладу освіти.

Виклад основного матеріалу дослідження 3 повним обгрунтуванням отриманих наукових результатів. Освітня інституція України переживає нелегкі часи. Особливо це стосується закладів професійно-технічної освіти. Перебування української профтехосвіти у складі радянської загальносоюзної освітньої системи, жорстка централізація планування іiі розвитку та управління нею свого часу мали позитивні результати й водночас негативні для iї майбутнього. Проведені дослідження [7, 259] доводять, що вся вертикаль управління професійно-технічної освіти характеризується авторитарним стилем, надмірним централізмом і контролем за їх діяльністю. В той час як в країні затребуваність на випускників професійних (професійно-технічних) училищ щороку зростає, держава не в змозі справитися з проблемою налагодження роботи цих закладів через економічні, фінансові та ряд інших причин, що накопичилися за роки.

Законодавче підгрунтя реформи професійно-технічної освіти визначені рядом документів: Указом президента України від 8 травня 1996 р. за № 322/96 «Про основні напрямки реформування професійно-технічної освіти в Україні»; Законом України «Про освіту» (2017 р.), Національною стратегією розвитку освіти України на період до 2021 р.; розпорядженням Кабінету Міністрів України від 12 червня 2019 р. за № 419 Про схвалення Концепції реалізації державної політики у сфері професійної (професійнотехнічної) освіти «Сучасна професійна (професійно-технічна) освіта» на період до 2027 року та іншими нормативно-правовими документами.

Проблема модернізації професійної освіти і навчання набула останнім часом міжнародного звучання. Поштовхом до цього стало прийняття Копенгагенської Декларації, Брюггського Комюніке про зміцнення європейського співробітництва у сфері професійної освіти та навчання на період 2011-2020 рр. (7 грудня 2010 р.). У цих документах наголошується, зокрема, на необхідності поліпшення управління у сфері професійної освіти і підготовки кадрів $[8,160]$.Реформування професійно-технічної освіти відбувається повільно. Ця освітянська ланка ще не посіла належного місця у загальному процесі перебудови суспільного виробництва і відтворення трудових ресурсів країни, хоча й має такий потенціал. Трансформацію професійно-технічної освіти сучасні фахівці розглядають комплексно, як філософську, соціально-економічну та педагогічну проблему $[8,136]$. Традиційна модель професійно-технічної освіти вичерпала себе і потребує оновлення та модернізації.

Ефективність упровадження та реалізації вищеназваних документів щодо реформування галузі залежить в тому числі від якості управління та управлінської компетентності керівника освітнього закладу. Вміння згуртувати колектив, налагодити роботу команди, сформувати іï місію, демонструвати цінності та принципи роботи, налаштувати ефективну комунікацію, створити та підтримувати належний психоемоційний клімат в організації - далеко не повний перелік обов'язків і затребуваних компетентностей сучасного керівника у справі формування корпоративної культури. Віднедавна окремі із згаданих компетентностей об'єднують у такі поняття як «soft-skills» (гнучкі або м'які навички) i «hard-skills» (тверді навички).

Важливість формування або привнесення корпоративної культури в організацію в сучасних умовах $\epsilon$ беззаперечною. Корпоративна культура $\epsilon$ стратегічним маркетинговим ресурсом, ефективним інструментом управління в руках керівника. 
Практика роботи багатьох організацій засвідчує, що ділова єдність залежить безпосередньо від духу та атмосфери, яка створюється в організації. Робота злагодженої команди є більш ефективною, ніж індивідуалізована праця, навіть високопрофесійна. Великі компанії, які стали світовими лідерами, вже давно відчули взаємозв'язок продуктивності праці від духовного й психологічної комфорту, ступеню єдності та спільності працівників.

Необхідною умовою формування корпоративної культури професійного (професійно-технічного) закладу освіти $\epsilon$, насамперед, усвідомлення керівником іiі значущості для організації, адже успішність підприємства чи організації вимірюється рівнем розвитку культури всередині професійного соціуму. Корпоративна (організаційна) культура як унікальний феномен кожної організації «є значною мірою як соціально-психологічним, так i організаційно-психологічним явищем, i потребує постійного розвитку, відстеження процесу його становлення та формування. ... Вона $€$ світоглядним, інтегруючим, адаптаційним чинником i разом 3 тим таким, що спрямований на змістовний розвиток корпорації» $[9,3]$ С. 3. Як зауважив Г. Хофштед, культура $\epsilon$ «колективним ментальним програмуванням» поведінки людей, особливостей їх діяльності в організації» $[10,3]$.

Не може бути організації без культури. Вона спонтанно формується у будь-якій організації через певний час після ії створення, оскільки люди неминуче привносять у неї свій індивідуальний досвід набутий в інших культурах. Первинно утворюється складна композиція індивідуальних культур, яка формує особистість організації, іiі унікальність. На перший погляд, здається, що корпоративна культура в організації сама по собі складається. Однак, сучасні дослідники доводять, що ії потрібно формувати, діагностувати, аналізувати, за потреби коригувати й змінювати. Культура організації це складна композиція ціннісних орієнтацій, вірувань, очікувань, норм та принципів, що поділяються більшістю колективу в організації. Потребу у іiі формуванні повинен відчувати, насамперед, керівник.

Роль керівника у формуванні та розвитку організаційної культури залишається визначальною. Про це влучно сказав Е. Шейн: «Можливо, єдиною, справді важливою справою, яку робить керівник, є створення культури й управління нею» $[11,78]$. «Сучасний керівник, незалежно від напряму його професійної діяльності, повинен не лише теоретично, а й практично орієнтуватися в питаннях загальної та прикладної культурології, соціології, психології і педагогіки, у процедурах прийняття управлінських рішень, мати тонкий смак, почуття гармонії, стилю, бути ерудованим, знати основи організаційної та управлінської культури, закони організаційної поведінки» $[12,8]$.

У часи трансформації професійно-технічних закладів освіти фокус особливої уваги керівника повинен бути спрямований саме на корпоративну культуру організації. Доведено, що будь-які зміни, тим більше стратегічні інноваційні впливають на стосунки в колективі. Більше того, як зазначає О. Мармаза, $[13,66]$ стратегічні зміни можуть супроводжуватися проблемою опору з боку колективу. Опір виникає, коли стратегічні зміни зумовлюють нові організаційні правила, схеми комунікацій, стиль управління. Ця проблема має бути передбачувана, очікувана керівником. До ключових елементів, що провокують опір в організації відносять силу (глибину) змін; масштаби змін; швидкість змін; послідовність змін (процедуру). Відтак, формуючи позитивне ставлення людей до змін, спрямовуючи їх поведінку, керівник створює сприятливі умови для їх впровадження. Ефективна комунікація керівника 3 колективом зробить процес змін безболісним, концептуально обгрунтованим, зрозумілим.

Діяльність керівника як освітнього менеджера, котрий більшість часу проводить 3 людьми, відноситься до найбільш ризикованих професійних груп щодо виникнення стресових станів. Зростання інтенсифікації праці, підвищення вимог до управлінської компетенції керівника передбачають його готовність і здатність долати стани 
напруження, повсякденні стресові ситуації. Адже саме управлінська діяльність є особливо вразливою до психологічного стресу і його наслідків. Дослідник О. Кокун [14, 247] до вагомих чинників, які можуть зумовити виникнення в керівників професійного стресу відносить перевантаження, конфлікти у колективі, необхідність перебування тривалий час у напруженості та невизначеності, високий рівень відповідальності тощо.

Зважаючи на те, що від керівника вимагають постійної актуалізації когнітивних, рефлексивних, емоційних та інших можливостей, актуальності набувають дослідження щодо психологізації управлінської діяльності та пошук ефективних технологій розвитку психологічної готовності керівників освітніх організацій до діяльності в умовах змін та трансформацій. Професор О. Бондарчук, $[2,84]$ спираючись на розуміння сутності освітньої технології С. Сисоєвої та В. Сластьоніна дає таке пояснення технології розвитку психологічної готовності керівників освітніх організацій до діяльності в умовах соціальних трансформацій. Це «... упорядкована сукупність дій, операцій та процедур (передавання психологічних знань, формування умінь i навичок застосування їх у практиці управлінської діяльності, розвиток професійно значущих особистісних якостей, стимулювання відповідної активності тих, хто навчається, регулювання та коригування перебігу педагогічного процесу, його контроль), що інструментально забезпечують досягнення прогнозованого результату (психологічну готовність до відповідної діяльності) у змінних умовах освітнього процесу» [2, 84]. Автор наводить складові технології, актуалізує ії затребуваність, водночас, наголошує, що досвід управлінської практики засвідчує невисокий рівень такої готовності у більшості управлінців.

Окреслений стан сучасного менеджменту освіти говорить про те, що психологічна необізнаність та непрофесіоналізм можуть призводити до психологічного дискомфорту в організації, напруженості у міжособистісних та міжгрупових стосунках, виникнення конфліктних ситуацій, таких деструктивних форм поведінки як мобінг, босинг тощо. Йдеться про врахування керівником не лише особливостей людини, ïi індивідуальних, психофізіологічних можливостей, а й специфіки колективу, взаємин повертикалі та по-горизонталі, питань гендерної рівності та недискримінації тощо.

Таким чином, роль керівника освітнього закладу у формуванні сприятливого морально-психологічного клімату та психологічної атмосфери в колективі, які $\epsilon$ складовою корпоративної культури організації, беззаперечна. А якщо врахувати те, що третина свідомого життя людини проходить на роботі, то психологічна обстановка в колективі має визначальний вплив не лише на результати праці, а й життя людини.

Формування корпоративної культури закладу професійно-технічної освіти $є$ складовою управлінської компетентності керівника. Корпоративну культуру треба сприймати як цілісне явище, як ідеологію управління, розуміючи під цим систему поглядів, ідей, цінностей, пов'язаним з управлінням організацією, стратегією її розвитку, способами та методами досягнення цілей, з діловою етикою організації (моральними принципами, нормами, правилами організації, що створюють фундамент процесу управління, його філософію та ідеологію [7, 257].

Організаційна культура це складний організм зі своїм обличчям, традиціями, репутацією, психоемоційним кліматом всередині організації. Корпоративна культура в основному невидима частина організації. Це не применшує іiі впливу на поведінку співробітників, але ускладнює аналіз і керування нею. Вона може бути детально регламентована документами, можуть бути декларовані лише окремі іiі принципи i, врешті, вона може існувати без будь-яких письмових правил.

Феномен корпоративної культури полягає в можливості відрізнити одну організацію від іншої та визначає їх успіх і стабільне становище на ринку. Атмосфера та соціальний клімат організації, іiі філософія, домінуюча система цінностей і стереотипів поведінки, норми та правила, які приймаються працівниками та безпосередньо формують їх поведінку - це елементи, які входять в культуру організації. 
Корпоративна культура допомагає здійснювати цілеспрямований вплив з боку керівників організації та менеджерів на людські ресурси організації з метою досягнення iii стратегічних цілей. Цей вплив відбувається через систему принципів, методів і механізмів оптимального комплектування, розвитку, мотивації та раціонального використання персоналу. В процесі управління персоналом корпоративна культура допомагає розвивати почуття причетності до справ організації (підприємства), заохочувати та залучати до спільної діяльності на благо підприємства, зміцнювати соціальні відносини, підтримувати індивідуальні ініціативи працівників, створювати атмосферу єдності менеджерів і персоналу у підприємстві, зміцнювати корпоративну родину.

Організації, що мають на меті ефективний розвиток, особливу увагу звертають на формування принципів корпоративної культури, які повинні відповідати критеріям стабільного та ефективного розвитку закладу. Впровадження та дотримання яких дозволить зробити корпоративну культуру могутнім інструментом управління персоналом, забезпечить цілісність організації, створить сприятливі умови для управління та сприятиме стабільному розвитку корпоративної культури.

Принципи корпоративної культури відображають вихідні засади, положення 3 ефективного управління персоналом. Кожне підприємство може самостійно розробляти принципи, головними з них є базові (загальні) принципи корпоративної культури, які можуть бути характерними та спільними для різних підприємств та спеціальні (індивідуальні) принципи, які враховують особливі, індивідуальні ознаки та властивості корпоративної культури підприємства та розробляються конкретно для певного підприємства.

Ядром корпоративної культури будь-якої організації є цінності, які формуються на певних правилах, законах, традиціях, які є обов'язковими для всіх і діють тільки тоді, коли цінності на ділі, а не на словах поділяють якщо не всі, то більшість працівників. Корпоративні цінності, як правило, включають у себе: статус організації та ії «обличчя»; розподіл повноважень та влади; ставлення до людей; критерії вибору на керівні посади; організацію роботи та дисципліну; стиль керівництва та управління; процеси прийняття рішень; поширення інформації та обмін нею; характер контактів; шляхи розв'язання конфліктів; оцінку ефективності роботи. Проголошені корпоративні цінності становлять основу корпоративної культури організації і закріплюються у кодексах чи правилах поведінки. Стрижневі цінності визначають напрями формування іiї стратегії та її іміджу і забезпечують спадковість підходів до їх реалізації.

Висновки. Таким чином, в процесі реформування та модернізації професійної (професійно-технічної) освіти все більшої актуальності набуває проблема управлінської компетентності керівника щодо створення ним корпоративної культури очолюваного ним закладу. Необхідною умовою формування корпоративної культури закладу освіти $\epsilon$, насамперед, усвідомлення керівником іiі значущості для організації, адже успішність організації вимірюється рівнем розвитку культури всередині професійного соціуму. Корпоративна (організаційна) культура як унікальний феномен кожної організації має своє обличчя, традиції, місію, філософію та ідеологію, репутацію, психоемоційний клімат всередині організації. Складність формування (привнесення) та управління корпоративною культурою закладу освіти пояснюється, насамперед, недооцінкою самих керівників такого ресурсу як корпоративна культура. Нове освітнє середовище закладів професійної (професійно-технічної) освіти потребує нових компетенцій від керівників. Успішність будь-якої організації вимірюється рівнем розвитку корпоративної культури.

\section{Список бібліографічного опису}

1.Карамушка Л. М. Психологія підготовки майбутніх менеджерів до управління змінами в організації : монографія / Л. М. Карамушка, М. В. Москальов. - К. ; Львів : Сподом, 2011. - 216 с.

2.Бондарчук О. І. Технологія розвитку психологічної готовності керівників закладів освіти до діяльності в умовах соціальних трансформацій / О. І. Бондарчук // Післядипломна освіта в Україні. - 2018. - № 1 - С. 84-87. 
3.Гоулман Д. Емоційний інтелект/ Даніел Гоулман; пер. з англ. С.-Л. Гумецької. -Х.: Віват, 2019. - 512 с.

4.Ясточкіна I. А. Професійна, соціальна та емоційна компетентності фахівця соціальної сфери: сутність та порівняльний аналіз / І.А. Ясточкіна // Науковий часопис Національного педагогічного університету імені М.П. Драгоманова. Серія 11. Соціальна робота. Соціальна педагогіка. - 2016. - Вип. 22. - С. 192 - 198.

5.Зарицька В. В. Теоретико-методологічні основи розвитку емоційного інтелекту у контексті професійної підготовки : монографія / В.В.Зарицька ; Класич. приват. ун-т. - Запоріжжя : Вид-во КПУ, 2010. - 304 с.

6.Бреус Ю. В. Емоційний інтелект як чинник професійного становлення майбутніх фахівців соціономічних професій у вищих навчальних закладах : автореф. дисертації ... канд. психол. наук: 19.00.07 / Ю.В.Бреус ; Київ. ун-т ім. Б. Грінченка. - Київ, 2015. - 20 с.

7.Управління розвитком професійно-технічної освіти в сучасних умовах: теорія і практика : монографія / [Г.В. Сльникова [та ін.]; за ред. В.І. Свистун. - К. : «НВП Поліграфсервіс», 2014. - 338 с

8.Професійний розвиток персоналу підприємств у країнах Європейського Союзу: посібник / Л. П. Пуховська, А. О. Ворначев, С. О. Леу ; за наук. ред. Л. П. Пуховської. - Київ: ІПТО НАПНУ. 2015. - 176 с.

9.Наконечна, Н. В. Психологічні умови розвитку корпоративної культури вищого навчального закладу приватної форми власності [Текст] : автореферат дис. ...канд. психол. наук : 19.00.10 / Наконечна Н. В. - Київ : ВНЗ «У-т економіки та права «Крок», 2016. - 20 с.

10. Hofstede G. Cultures and Organizations [Text]/G.Hofstede. - London: Harper Cjllins Business, 1991. - P.3-5.

11. Шейн Э. Х. Организационная культура и лидерство / Э.Х. Шейн; [пер. с англ.]; под ред. В.А. Спивака. - СПб.: Питер, 2002. - 336 с.

12. Палеха Ю. І. Ключі до успіху, або Організаційна та управлінська культури: навч. посіб. / Ю. І. Палеха. - 2-ге вид. доп. - К.: Вид-во Європ. ун-ту, 2002. - 337 с.

13. Мармаза О.І. Менеджмент освітньої організації / О. І. Мармаза. - Х.: ТОВ «Щедра садиба», 2017. - 126 с.

14. Психофізіологічне забезпечення становлення фахівця у професіях типу «людина-людина» : монографія / За ред. О.М. Кокуна. - Кіровоград : Імекс-ЛТД, 2013. - 266 с.

\section{References}

1.Karamushka L. M. Psykhologhija pidghotovky majbutnikh menedzheriv do upravlinnja zminamy v orghanizaciji : monoghrafija / L. M. Karamushka, M. V. Moskaljov. - K. ; Ljviv : Spodom, 2011. - 216 s.

2.Bondarchuk O. I. Tekhnologhija rozvytku psykhologhichnoji ghotovnosti kerivnykiv zakladiv osvity do dijaljnosti v umovakh socialjnykh transformacij / O. I. Bondarchuk // Pisljadyplomna osvita v Ukrajini. - 2018. - \# 1 - S. 84-87.

3.Goulman D. Emocijnyj intelekt/ Daniel Goulman; per. z anghl. S.-L.Ghumecjkoji. -Kh.: Vivat, 2019. - $512 \mathrm{~s}$.

4.Jastochkina I. A. Profesijna, socialjna ta emocijna kompetentnosti fakhivcja socialjnoji sfery: sutnistj ta porivnjaljnyj analiz / I.A. Jastochkina // Naukovyj chasopys Nacionaljnogho pedaghoghichnogho universytetu imeni M.P. Draghomanova. Serija 11. Socialjna robota. Socialjna pedaghoghika. - 2016. - Vyp. 22. - S. 192-198.

5.Zarycjka V. V. Teoretyko-metodologhichni osnovy rozvytku emocijnogho intelektu u konteksti profesijnoji pidghotovky: monoghrafija / V. V. Zarycjka ; Klasych. pryvat. un-t. - Zaporizhzhja : Vyd-vo KPU, 2010. - 304 s.

6. Breus Ju. V. Emocijnyj intelekt jak chynnyk profesijnogho stanovlennja majbutnikh fakhivciv socionomichnykh profesij u vyshhykh navchaljnykh zakladakh : avtoref. dysertaciji ... kand. psykhol. nauk: 19.00.07 / Ju. V. Breus ; Kyjiv. un-t im. B. Ghrinchenka. - Kyjiv, 2015. - 20 s.

7.Upravlinnja rozvytkom profesijno-tekhnichnoji osvity v suchasnykh umovakh: teorija i praktyka : monoghrafija / [Gh.V. Jeljnykova [ta in.]; za red. V.I. Svystun. - K. : «NVP Polighrafservis», 2014. - 338 s

8.Profesijnyj rozvytok personalu pidpryjemstv u krajinakh Jevropejsjkogho Sojuzu: posibnyk / L. P. Pukhovsjka, A. O. Vornachev, S. O. Leu ; za nauk. red. L. P. Pukhovsjkoji. - Kyjiv: IPTO NAPNU. 2015. - $176 \mathrm{~s}$.

9.Nakonechna, N. V. Psykhologhichni umovy rozvytku korporatyvnoji kuljtury vyshhogho navchaljnogho zakladu pryvatnoji formy vlasnosti [Tekst] : avtoreferat dys. ...kand. psykhol. nauk : 19.00.10 / Nakonechna N. V. - Kyjiv : VNZ «U-t ekonomiky ta prava «Krok», 2016. $-20 \mathrm{~s}$.

10. Hofstede G. Cultures and Organizations [Text]/G.Hofstede. - London: Harper Cjllins Business, 1991. - P.3-5.

11. Shejn Э. Kh. Orghanyzacyonnaja kuljtura y lyderstvo / Э.Kh. Shejn; [per. s anghl.]; pod red. V.A. Spyvaka. - SPb.: Pyter, 2002. $-336 \mathrm{~s}$.

12. Palekha Ju. I. Kljuchi do uspikhu, abo Orghanizacijna ta upravlinsjka kuljtury: navch. posib. / Ju. I. Palekha. - 2-ghe vyd. dop. - K.: Vyd-vo Jevrop. un-tu, 2002. - 337 s.

13. Marmaza O.I. Menedzhment osvitnjoji orghanizaciji / O. I. Marmaza. - Kh.: TOV «Shhedra sadyba», 2017. - $126 \mathrm{~s}$.

14. Psykhofiziologhichne zabezpechennja stanovlennja fakhivcja u profesijakh typu «ljudyna-ljudyna»: monoghrafija / Za red. O.M. Kokuna. - Kirovoghrad : Imeks-LTD, 2013. - 266 s.

Дата подання публікації 20.12.2020 p. 